\title{
A BIOLOGICAL AND CHEMICAL SURVEY OF THE QU'APPELLE LAKES
}

by D. R. Cullimore, Water Quality Research Laboratory, Regina

In Southern Saskatchewan, the climate is semi-arid with a precipitation often well below 16" per year. As a result of this, water is not plentiful and is subject to considerable losses from evaporation and leaching. The $\mathrm{Qu}$ 'Appelle Basin forms one of the principal catchments in this area and water collects directly into the basin or is released into the system from Diefenbaker Lake. The river flows slowly east into the Assiniboine River just inside the province of Manitoba. Within this basin there are eight major lakes. Seven are on the Qu'Appelle River itself. Moving downsteam, these are Buffalo Pound (source of the drinking water for Regina and Moose Jaw), Pasqua, Echo, Mission, Katepwa (the four fishing lakes), Crooked and Round Lakes. These lakes vary in depth from $5^{\prime}$ to $45^{\prime}$ at the middle, and in width from $\frac{1}{2}$ to $1 \frac{1}{2}$ miles. To the north is the largest lake, Last Mountain Lake, which feeds into the Qu'Appelle River below Craven. This is a much longer lake with a much greater volume having depths up to $75^{\prime}$ at the centre. Water entering these lakes comes from a variety of sources. These include release from Diefenbaker Lake, run-off from the land, effluent from urban sewage treatment plants, inputs from underground water systems, and direct precipitation. Each of these sources contributes not only certain volumes of water but also nutrients which encourage the growth of algae and water plants in the lakes and river systems. The Qu'Appelle lakes have long been known to support extensive algal growth. Hind in 1858, while on an expedition proceeding along the valley, observed that "an abundant growth of green confervae (algae) covered the surface" of the fishing lakes. Crooked Lake was described by Dickenson in 1857 as having water which at times was "rendered very disagreeable by the great quantity of confervae... now decaying and rotting under the hot sun". It is not surprising therefore that today the Qu'Appelle lakes still possess a water quality problem caused by abundant algal growth (eutrophication). As these lakes become a greater focus of attention for recreation, irrigation and wildlife reserves, there develops a greater need to improve the quality of their waters. In 1969, the Qu'Appelle Basin Study was initiated as a federal-provincial project to evaluate water quality, hydrological and socio-economic problems connected with this basin. As a part of this study, the University of Saskatchewan, Regina Campus undertook an extensive study of the biological and chemical factors which could affect algal and water plant growth in the Qu'Appelle lakes.

\section{Factors affiecting Algal Growth in the Qu'Appelle lakes}

There are many different types of algae present in the lakes, but all are affected by availability of nutrients in the water. In total, there are between thirteen and eighteen chemical elements which in some form or other can control algal growth. For example, in 1970, the amount of algal growth in the lake on the Condie nature reserve was restrained by a deficiency of magnesium. However, five elements are required in large quantities to support algal growth. These are carbon, nitrogen, phosphorus, sulphur and potassium. In the Qu'Appelle system, carbon, sulphur and potassium are always abundant and the amount of algal growth tends to be controlled by the amount of nitrogen and phosphorus present in the water. Both of these nutrients enter the lakes and rivers from all the sources discussed above. Temperature also affects the amount of algal growth since different species of algae initiate growth at various temperatures. In most cases, the temperature which initiates 
nutrients to the water system. These include not tilling across creek beds, grassing back from creeks, not fertilising fields in the fall, and not depositing animal wastes in creeks, run-off areas, or on lake or river ice in the winter. In years when the run-off is low, the nutrients entering the system from this source is low.

Although Regina and Moose Jaw both treat the sewage by primary and secondary processes, the effluent being discharged into the Wascana and Moose Jaw Creeks is rich in phosphates and nitrogen and studies are underway by different agencies to evaluate the various procedures for removing these nutrients from the system by tertiary treatment. The percentage contribution of these effluents to the nutrient loads in the lakes is very much affected by the degree of spring run-off. In a year of high run-off, the contribution is less than in a year of low run-off. This relationship is displayed in Figure 2. One of the major dangers is that as Regina grows in size as a result of urban drift and economic developments so the input of nutrients from these sources will continue to increase. It is predicted that Regina could reach a mean population of 192,000 by 1985 and 257,000 by 2000 A.D. with corresponding increases in nitrogen and phosphate outputs of $37 \%$ by 1985 and $83 \%$ by the year 2000 . Such a population growth would substantially increase the size of the algal blooms above the levels seen today. Bioassays conducted in the laboratories here indicate that some lakes are already reaching a maximum tolerance above which major changes would occur in the floristic composition of the lake. Of their potential algal productivity,
Low

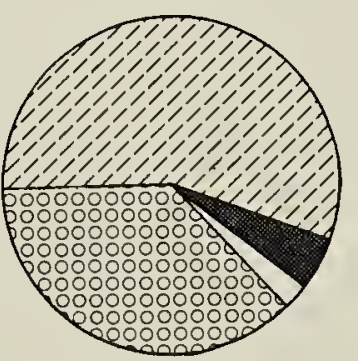

NITROGEN

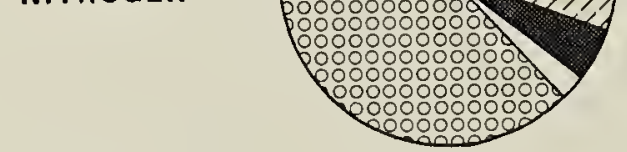

PHOSPHATE

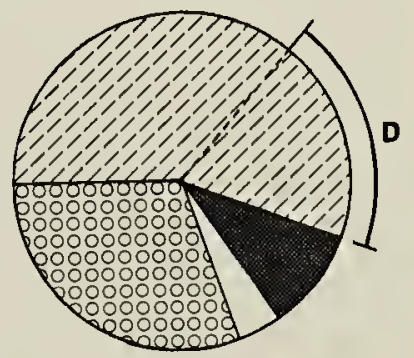

HIGH
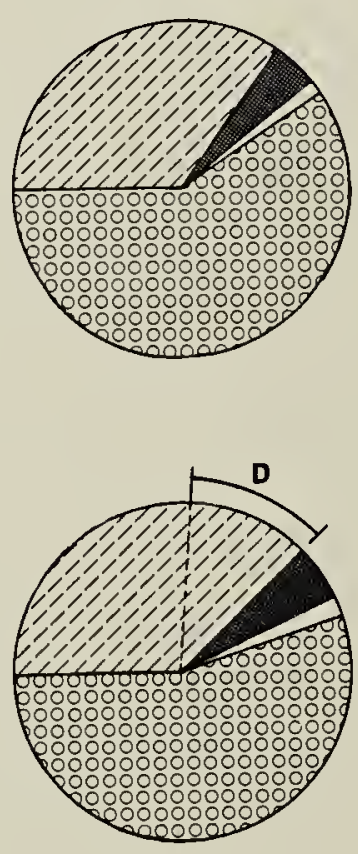

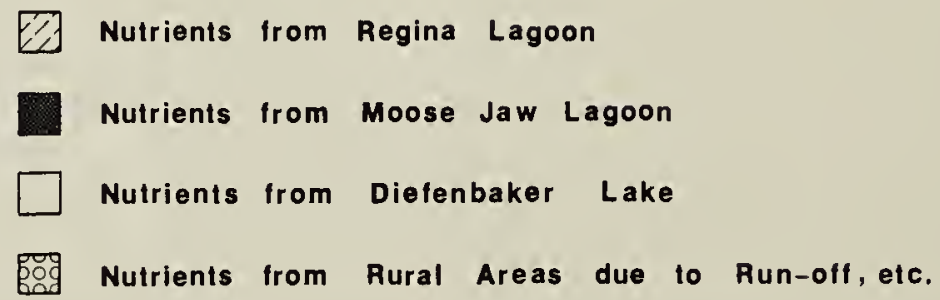

Fig. 2. Approximate breakdown of the sources of nitrogen (upper pair) and phosphates (lower pair) during a year of low run-off (left) and high run-off (right). The marked segment from Regina lagoon shown as D indicates the amount of phosphates arising from detergents. 
Mission Lake was found in the fall of 1970 to be $46 \%$ of the maximum, Pasqua 33\%, Last Mountain 24\%, Crooked $12 \%$, Buffalo Pound $5 \%$, and Round $3 \%$. Echo Lake had its highest production in the spring of 1971 with $18 \%$ of the maximum potential. These assays also showed that none of the common algae present in the lakes could grow in greater than 3 parts per million (ppm) phosphorus as phosphate but could continue to respond with up to $12 \mathrm{ppm}$ of additional nitrogen as ammonium nitrate. If the algal bloom is not to get any greater than it already is, then at least the additional nutrients entering the system from the increased population size of Regina will have to be removed. If all the nutrients were to be removed and the water recycled as drinking water within the city, a marginal or significant improvement in the lakes could be expected.

Water in Diefenbaker Lake is of a much higher quality than the water in the Qu'Appelle lakes and as a result of releases into the river, improvements in the quality of Buffalo Pound Lake have already been observed together with a greatly reduced algal bloom. Some underground water also adds nutrients to the system from different sources but as yet the extent of these is still to be determined.

Some direct nutrient inputs occur in the lakes through wildlife, soil erosion, cottagers discharging waste directly into the lakes and cattle with free access to the lakes. With the exception of the wildlife, all these sources could be controlled.

The movement of nutrients through the lakes and river system is controlled partly by the rate of water flow and partly by the rate at which the nutrients are deposited into and released from the sediments. Whereas the water flow has been regularly monitored, no monitoring has yet been conducted on the sediment. Since much of the water flow occurs during the spring run-off, it is not surprising that this is also the time when nutrients move most rapidly through the lakes. The fishing lakes are a good example of this type of movement. Pasqua Lake (the first lake in the chain) received $65 \%$ of its phosphate and $43 \%$ of its nitrogen load from treated Regina effluent during the fall of 1970. Because this continued during the winter at which time there is little water movement, the nitrogen level was raised from 1.9 to $4.1 \mathrm{ppm}$ and phosphate 0.9 to $1.4 \mathrm{ppm}$ in the lake from September 1970 to February 1971. Thus Pasqua Lake was acting

Table 1: Algae present in the Qu'Appelle lakes

Euglenophyceae

Euglena sp.

Chlorophyceae

Actinastrum sp.

*Ankistrodesmus sp.

Chlamydomonas sp.

Chlorella sp.

Cladophora sp.

Closterium sp.

Coelastrum sp.

Cosmarium sp.

Geminella sp.

Gloeocystis sp.

Golerkiria sp.

Lagerheinia sp.

*Pediastrum sp.

Phytoconis sp.

Rhizoclonium sp.

* Scenedesmus sp.

Spirogyra sp.

Spongiochloris sp.

Stichococcus sp.

Stigeoclonium sp.

Tetraedron sp.

Cyanophyceae

Anabaena sp.

*Aphanizomenon sp.

Arthrospira sp.

Calothrix sp.

Lyngbya sp.

Merismopedia sp.

*Microcystis sp.

Oscillatoria sp.

Bacillariophyceae

Cymbella sp.

Flagilaria sp.

Gomphonema sp.

Gyrosigma sp.

Navicula sp.

* Nitzschia sp.

Rhoicospheria sp.

* Frequently abundant in the lakes 
as a "nutrient store" during the winter reaching very high concentrations. After the spring run-off, the nutrients which were in Pasqua Lake had been flushed down stream. These nutrients amounted to 570,000 lbs. nitrogen and 173,000 lbs. phosphate. The nitrogen was found to have moved into Mission and Katepwa Lakes whilst some phosphate increases were found in Echo and Katepwa Lakes. Thus the nutrients which moved through this period would influence the subsequent growth that could be expected to occur in Echo, Mission and Katepwa Lakes.

Typical algae found in the lakes are listed as table 1 . The more common algae are indicated by an asterisk.

It becomes clear that the improvement of the water quality in the $\mathrm{Qu}$ 'Appelle lakes is not a simple matter but involves many factors. The addition of tertiary treatment facilities to the sewage treatment plants of Regina, Moose Jaw and the other towns would do much to reduce nutrient input. Control of run-off, improved practices by cottagers and farmers (including feedlot operators) would also have an effect. However, the actual effect that all of these practices will have on the size and extent of the algal blooms cannot as yet be determined. This must await the development of satisfactory models by which all of these factors can be weighted so that their effect alone or in combination on algal growth can be determined.

\section{Factors affecting Water Plant Abundance in the Qu'Appelle lakes}

Eight species of water plants are frequently found in the Qu'Appelle lakes. These include lesser duckweed (Lemna minor), coontail (Ceratophyllum demersum), spiked water milfoil (Myriophyllum exalbescens), sago pondweed (Potamogeton pectinatus), Richardson's pondweed (Potamogeton vaginatus), three square rush (Scirpus americanus), and the common great bulrush (Scirpus validus). Some differences were noted in the percentage abundance of these various plants from lake to lake during a survey conducted in July 1971. In Last Mountain and Buffalo Pound Lakes, Richardson's pondweed was most abundant whilst in the remaining lakes, sago pondweed was generally dominant. One exception was in Echo Lake where there was an abundance of spiked water milfoil. In some lakes, coontail was also found to be abundant along with Richardson's pondweed. Attempts were made to correlate the presence of these plants to other measured factors to determine which factors, if any, affected the relative dominance of the different species. A clear correlation was found between the levels of total phosphate in $\mathrm{ppm}$ in the water and the composition of the weed flora. At phosphate levels below 0.2 ppm Richardson's pondweed and coontail were equally abundant. As the concentration rose to $0.5 \mathrm{ppm}$, coontail disappeared from the flora and was replaced by sago pondweed as the co-dominant plant. In water with phosphate values between 0.5 and $1.0 \mathrm{ppm}$ phosphate, the sago pondweed became more dominant until above 1.0 ppm phosphate when this species was completely dominant except in Echo Lake where high phosphate values were accompanied by high nitrate values and here spiked water milfoil was the most abundant.

From this data, it would appear that the composition of water plants in the lakes does reflect the levels of phosphate in the water and that a local variation may reflect an input of additional phosphate or a dilution effect caused by a spring which releases low phospate water into the lake.

\section{Conclusions}

The Qu'Appelle lakes are some of the most eutrophic lakes in North America and any attempt to improve the water quality of this system is going to involve considerable expenditures which must be made in the correct areas. In the meantime, there are a number of steps which individuals can take to reduce the level of nutrients entering the lakes. Cottagers should stop discharging any liquid or solid waste into the lakes. Farmers 
should prevent cattle from entering the lakes, stop cultivating across creek beds, stop placing animal wastes in areas where the spring thaw will cause the material to enter the water system, and resist the temptation to apply fertiliser in the fall in areas where high run-off is likely to occur.

\section{ACKNOWLEDGMENTS}

The author would like to express sincere gratitude to the Qu'Appelle Basin Study Board and the Saskatchewan Research Council for financial support of this work; to members of the Qu'Appelle Study Board for the data relating to nutrient load and run-off which had been reported by other agencies; and to others who aided in many aspects of this study.

Note: At the time of going to press, the Qu'Appelle Basin Study Public Report was in the hands of the printers and was expected to be released before this article. Persons wishing to learn more of this study are urged to read this report which should be available through libraries.

\section{The Blue Jay Bookshelf}

FLORA OF THE PRAIRIE PROVINCES, PART III, Connatae. 1972. By Bernard Boivin. 224 pp. Issued as Provancheria \#4, being Memoirs of the Louis-Marie Herbarium, Faculty of Agriculture, Laval University, Quebec City. Reprinted from Phytologia 22: 315-398 (1972) and 23:1-140 (1972). Available from the Blue Jay Bookshop, Box 1121, Regina, as are the preceding two parts.

This is the third of the four-part series on the flora of the three prairie provinces upon which Dr. Boivon has been working since 1949 at least. Part I was reviewed in this magazine, June, 1968; part II, September, 1969.

In Boivin's treatment of the subject, "Connatae" includes the bulk of what used to be called "Gamopetalous" or "Sympetalous Dicotyledons" those families of dicots in which the often showy corolla is built up of petals fused into one sheet of tissue. Among these, Ericaceae (Heath Family), being woody, was, along with its relatives, treated in Part I; Caprifoliaceae (Honeysuckles) was also included in Part I for the same reason; Primulaceae (Primrose Family) appeared in Part II among the polypetalous dicots. However, here in Part III we find the well-known families Solanaceae (Potato Family), Scrophulariaceae (Snapdragon Family), Polemoniaceae (Phloxes), Boraginaceae (Blue Bur
Family), Labiatae (Mints), and Gentianaceae (Gentians), besides assorted smaller families. The mighty family Compositae (Sunflower Family) appears after these others and takes up over half the book. Because of the presence of Compositae in this part, a more than usual proportion of large, difficult, and controversial genera in which the species are often not clearly defined come up for treatment. These include Solidago, Aster, Erigeron, Antennaria, Senecio, Arnica, Helianthus, and Artemisia. On this matter Dr. Boivin has stated his strategy in the discussion of Aster simplex on pages 119-121.

The trouble with writing a book review is that one must pass over the 999 items out of 1000 which offer no scope for objections, for these items have been treated according to the highest standards of excellence; but one is obligated to pick out the one defect per thousand items. So it is with this review. Part III extends the work of its predecessor parts in giving us a complete, concise, and up-to-date flora of the Prairie Provinces, than which nothing more favourable need be said. But I noted a couple of errors, along with several items which will be found unusual by users of previous floras.

As for the errors: 1) There appears to be something seriously muddled in the primary key to the families of 